\title{
Determinan Nilai Pelanggan dan Implikasinya pada Dependensi Pelanggan Bengkel Suv Premium
}

\author{
ADITYA WARDHANA \\ Fakultas Komunikasi dan Bisnis, Universitas Telkom, Jl. Telekomunikasi No. 1, Bandung 40257 \\ email: adityawardhana@telkomuniversity.ac.id
}

\begin{abstract}
The implementation of ASEAN Economic Community (AEC) for Indonesia making its big market more capitalized and and grow rapidly. The Indonesian automotive industrial market has become ASEAN's biggest auto market. Automotive products in Indonesia is divided into two is a variant of commercial vehicles and passenger vehicle. Passenger vehicle is divided into three types namely: sedan, multi purpose vehicle (MPV), sport utility vehicle (SUV). The aim of this study is to investigate the determinants of customer value such as service quality and customer relationship management (CRM) and its implications on customer dependence. This research using a method of survey with a number of population 63.015 customers and 400 respondents as customers at premium SUV authorized service station in urban areas in West Java with using slovin formula. Analysis of data using path analysis. The result of this research concluded that the service quality and customer relationship management influenced partially significant on the perceived value of customers of car workshop premium SUV.
\end{abstract}

Keywords: service quality, customer relationship management, customer value

\begin{abstract}
Abstrak. Penerapan ASEAN Economic Community (AEC) bagi Indonesia akan lebih mengkapitalisasikan pasarnya yang besar dan tumbuh dengan pesat. Indonesia telah menjadi pasar otomotif terbesar di ASEAN. Produk otomotif di Indonesia terbagi menjadi dua varian, yaitu kendaraan penumpang dan kendaraan niaga. Kendaraan penumpang terbagi menjadi tiga jenis, yaitu: Sedan, Multi Purpose Vehicle (MPV), dan Sport Utility Vehicle (SUV). Studi ini menyelidiki determinan nilai pelanggan yang meliputi kualitas pelayanan dan manajemen kerelasian pelanggan serta implikasinya pada dependensi pelanggan. Penelitian ini menggunakan metode survei dengan populasi sebesar 63.015 dan sampel sebanyak 400 responden sebagai pelanggan bengkel resmi mobil SUV premium di wilayah perkotaan di Jawa Barat menggunakan rumus Slovin. Analisis data menggunakan analisis jalur. Hasil penelitian ini menyimpulkan bahwa kualitas pelayanan dan manajemen kerelasian pelanggan berpengaruh secara parsial dan signifikan terhadap nilai pelanggan bengkel resmi mobil SUV premium.
\end{abstract}

Kata kunci: kualitas pelayanan, manajemen kerelasian pelanggan, nilai pelanggan

\section{Pendahuluan}

Penerapan ASEAN Economic Community (AEC) bagi Indonesia akan lebih mengkapitalisasikan pasarnya yang besar dan tumbuh dengan pesat. Pertumbuhan pasar dan industri otomotif Indonesia sejak tahun 2011 telah melebihi Cina dan Thailand, dan hingga saat ini Indonesia telah menjadi pasar otomotif terbesar di ASEAN. Manufaktur lokal otomotif Indonesia akan mengalami lompatan besar seiring semakin menariknya posisi Indonesia sebagai pusat kawasan untuk produksi otomotif. Tingkat ekspor diperkirakan akan tumbuh karena ASEAN Economic Community (AEC) dan (China-ASEAN Free Trade Area [CAFTA]) akan mempermudah para Original Equipment Manufacturer (OEM) untuk mendirikan basis perakitan dan memasok ke pasar lain (Nurmayanti, 2013).

Sepanjang tahun 2012, perkembangan pasar otomotif nasional masih dikuasai oleh

Received: 1 Juni 2014, Revision: 2 April 2015, Accepted: 18 Juni 2015

Print ISSN: 0215-8175; Online ISSN: 2303-2499. Copyright@2015. Published by Pusat Penerbitan Universitas (P2U) LPPM Unisba Terakreditasi SK Kemendikbud, No.040/P/2014, berlaku 18-02-2014 s.d 18-02-2019 
para ATPM yang merupakan pemain lama, seperti Astra Group (pangsa pasar 53,69\%), Indomobil Group (pangsa pasar 16,61\%), dan pangsa pasar sisanya sebesar $29,70 \%$ dikuasai oleh beberapa ATPM antara lain, PT Honda Prospect Motor (Honda), PT Krama Yudha Tiga Berlian Motor (Mitsubishi), PT Mazda Motor Indonesia (Mazda), PT Ford Motor Indonesia (Ford), PT General Motor Auto World Indonesia (Chevrolet), PT Kia Mobil Indonesia (Kia), PT Hyundai Indonesia Motor (Hyundai), PT Auto Euro Indonesia (Renault), PT Proton Edar Indonesia (Proton) dan lain-lain.

Produk otomotif di Indonesia terbagi menjadi dua varian, yaitu kendaraan penumpang dan kendaraan niaga. Kendaraan penumpang terbagi menjadi tiga jenis yaitu: Sedan, Multi Purpose Vehicle (MPV), dan Sport Utility Vehicle (SUV) yang masingmasing dibagi lagi berdasarkan besarnya kapasitas mesin. Volume penjualan mobil masih didominansi oleh varian penumpang, sehingga trend pasar mobil nasional mengarah kepada MPV pada peringkat pertama (pangsa pasar $62 \%$ ), serta SUV pada peringkat kedua (pangsa pasar 17\%), dan Sedan pada peringkat ketiga (pangsa pasar $4 \%$ ). Sedangkan pangsa pasar untuk kendaraan niaga sebesar 17\% (Kompas, 13 April 2012).

Kendaraan jenis SUV diminati oleh para profesional, pengusaha, maupun para eksekutif muda, karena SUV memiliki keunggulan dibandingkan jenis lainnya seperti kabin yang lapang, desain bodi yang gagah, posisi mengemudi (ground clearance) yang tinggi(Tanoso, 2012).

Hasil penjualan Peringkat Lima Besar Merek dan Jenis Kendaraan SUV Premium Tahun 2010-2012 dapat dijelaskan pada gambar berikut :

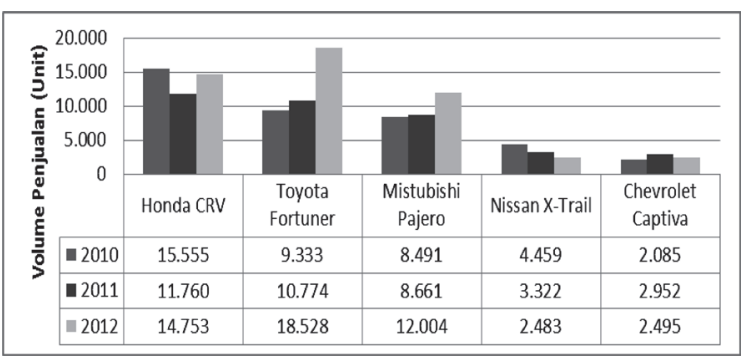

Sumber: Gaikindo 2013

Gambar 1. Hasil Penjualan Peringkat Lima Besar Merek dan Jenis Kendaraan SUV Premium Tahun 2010-2012

Kenaikan minat konsumen pada kendaraan SUV premium didorong karena teknologi kenyamanan berkendara dan model yang fashionable yang ditawarkan oleh kelas SUV Premium ini sehingga dapat digunakan baik oleh pria maupun wanita.

Dengan semakin banyaknya kompetitor dan pemain baru di pasar SUV khususnya SUV Premium, semakin mendorong para ATPM untuk terus menerus memberikan pelayanan yang baik (Tanoso, 2012). Berdasarkan data dari Gabungan Industri Kendaraan Bermotor Indonesia (Gaikindo), potensi pasar kendaraan bermotor roda empat di Jawa Barat cukup besar, yaitu dengan pangsa pasar $18 \%$ dari penjualan nasional.

Berdasarkan data Gaikindo dan Dispenda Jawa Barat dan Banten tahun 2013, volume penjualan mobil di Jawa Barat selama tahun 2010 sebanyak 137.646 unit, tahun 2011 sebanyak 160.809 unit, tahun 2012 sebanyak 184.679 unit. Sedangkan porsi kendaraan SUV Premium di Jawa Barat selama tahun 2010 sebanyak 23.398 unit, tahun 2011 sebanyak 28.946 unit, dan tahun 2012 sebanyak 33.796 unit.

Berdasarkan survei pendahuluan (preliminary research), secara umum masih banyak terdapat permasalahan yang terkait dengan dependensi pelanggan. Tingkat dependensi pelanggan bengkel resmi tersebut disebabkan karena persepsi nilai yang diterima oleh pelanggan bengkel resmi (customer value) seperti tampak pada Gambar 2 berikut ini :

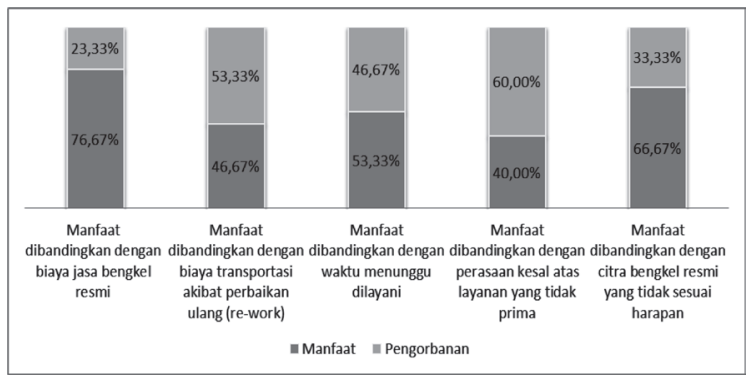

Sumber : Hasil Premiminary Research 2012

Gambar 2. Persepsi Pelanggan Terkait Nilai Pelanggan di Bengkel Resmi SUV Premium di Jawa Barat Tahun 2012

Berdasarkan data pada Gambar 2 tersebut di atas dapat disimpulkan bahwa secara umum masih banyak terdapat permasalahan yang terkait dengan nilai pelanggan atas jasa bengkel resmi kendaraan roda empat, khususnya jenis SUV Premium di Jawa Barat yang dapat menyebabkan pelanggan dapat memilih untuk menggunakan jasa bengkel resmi atau non-resmi yang memiliki teknologi. 
Berdasarkan uraian tersebur di atas, maka tujuan dalam penelitian ini adalah untuk mengkaji pengaruh kualitas pelayanan dan manajemen kerelasian pelanggan terhadap nilai pelanggan secara parsial dalam menggunakan jasa pelayanan bengkel resmi kendaraan SUV Premium di wilayah perkotaan di Jawa Barat, pengaruh kualitas pelayanan dan manajemen kerelasian pelanggan terhadap nilai pelanggan secara simultan dalam menggunakan jasa pelayanan bengkel resmi kendaraan SUV Premium di wilayah perkotaan di Jawa Barat, dan pengaruh nilai pelanggan terhadap dependensi pelanggan dalam menggunakan jasa pelayanan bengkel resmi kendaraan SUV Premium di wilayah perkotaan di Jawa Barat.

\section{Teori Kualitas Pelayanan}

Ketepatan strategi pemasaran jasa dari suatu perusahaan ditentukan oleh kualitas pelayanan (service quality) yang ditawarkan. Hal ini senada dengan yang dikemukakan Ehinlanwo dan Zairi (1996) bahwa efektivitas strategi pemasaran yang meliputi kualitas jasa akan berbeda untuk setiap merek kendaraan dan yang dikemukakan ole Definisi tentang kualitas pelayanan (service quality) dikemukakan oleh Zeithaml \& Bitner (2009:3) menyatakan bahwa kualitas pelayanan memfokuskan khususnya pada dimensidimensi pelayanan.

Menurut Parasuraman, Zeithaml, dan Berry (1988) dalam Zeithaml \& Bitner (2009:103) dan Lovelock \& Wright (2011: 406) menyatakan bahwa lima unsur yang menentukan kualitas pelayanan, yaitu: tangible, responsiveness, reliability, assurance, dan empathy. Hardiansyah (2012:193) menyatakan bahwa teknik analisis yang digunakan melalui pendekatan Metode Servqual yang terdiri dari lima dimensi yaitu tangible (berwujud), reliability (kehandalan), responsiveness (respons/ tanggapan), assurance (jaminan), dan empathy (empati).

Bukti nyata (tangibles) mencerminkan fasilitas fisik jasa seperti gedung kantor, ruangan, dan petugas. Hal dapat dipercaya (reliability) mencakup konsistensi dari penampilan dan keandalan jasa. Cepattanggap (responsiveness) meliputi kesiapan dan kecepat tanggapan petugas untuk menyediakan jasa. Jaminan (assurance) meliputi keterampilan petugas, keramahan petugas, kepercayaan, keamanan dalam penggunaan jasa. Empati (empathy) mencakup kemudahan komunikasi, dan pemahaman terhadap kebutuhan konsumen. Dengan demikian kualitas pelayanan akan ditentukan oleh kemampuan perusahaan dalam menampilkan unsur-unsur kualitas pelayanan tersebut.

\section{Teori Manajemen Kerelasian Pelanggan}

Kottler \& Keller (2012: 157) menyatakan bahwa manajemen kerelasian pelanggan (CRM) adalah proses yang dilakukan secara hati-hati dalam mengelola informasi rinci tentang pelanggan perorangan dan semua pelanggan sasaran untuk memaksimalkan kesetiaan.

Dari penelitian Alipour \& Mohammadi (2011: 8) dan Devaraja (2012: 19) dapat disimpulkan bahwa segmentasi pelanggan dilakukan untuk mengidentifikasi penempatan nilai dan mendapatkan manfaat yang sangat baik dalam hubungan jangka panjang dengan pelanggan atau kelompok pelanggan tertentu melalui penerapan CRM mengingat tidak semua pelanggan adalah sama-sama dapat memberikan keuntungan (equally profitable) atau sama-sama penting (equally important).

McNaughton et al. (2002: 12) menyatakan bahwa keterlibatan pelanggan dalam proses pelayanan mendorong perlunya hubungan yang dekat dan saling percaya dalam rangka meningkatkan nilai yang dirasakan pelanggan, dan hubungan semacam itu secara logis dipelihara oleh perusahaan yang berorientasi pasar. Konsekuensi yang transparan akibat kedekatan layanan dengan pelanggan memungkinkan dibentuknya kesan atas komitmen perusahaan untuk menciptakan nilai pelanggan.

Buttle (2005:19), Cravens (2009:167), dan Kandampully (1998:434) menyatakan bahwa manajemen kerelasian pelanggan akan meningkatkan kinerja pemasaran bagi penyedia jasa. Karena perusahaan menjadi lebih selektif dalam memilih pelanggan mana yang akan perusahaan layani, maka perusahaan menggunakan manajemen kerelasian pelanggan untuk mempertahankan pelanggan yang sudah ada sekaligus untuk membangun hubungan jangka panjang yang menguntungkan bagi perusahaan yang berdampak pada peningkatan nilai pelanggannya.

\section{Teori Nilai Pelanggan}

Kotler \& Keller (2012:147)menyatakan bahwa nilai yang diterima berdasarkan 
persepsi pelanggan adalah evaluasi pelanggan pontensial terhadap perbedaan antara semua manfaat dengan semua biaya dari suatu penawaran yang dirasakan dan alternatif lainnya. Cravens (2009:7) menyatakan bahwa nilai untuk pembeli (nilai yang dirasakan oleh pembeli) terdiri atas manfaat dan biaya yang dihasilkan dari pembelian dan penggunaan produk. Nilai yang unggul terjadi ketika ada manfaat bersih yang positif. Nilai pelanggan yang unggul sebagai hasil dari suatu pengalaman dalam menggunakan yang sangat menguntungkan dibandingkan dengan harapan dan nilai yang ditawarkan pesaing.

Penelitian yang dilakukan $\mathrm{He}$ (2001:1172) menyimpulkan bahwa terdapat dua faktor yang mendasari preferensi pelanggan terhadap atribut-atribut nilai dari suatu produk, yaitu faktor kesukaan (interest factor) dan faktor biaya (cost factor). Persepsi pelanggan terhadap nilai, terutama timbul karena adanya perbedaan antara pengorbanan dan manfaat sebagaimana teori Kotler tentang nilai yang diterima pelanggan (customer delivered value). Nilai yang diterima pelanggan mengindikasikan adanya perbedaan dalam nilai produk yang diterima pelanggan dalam kondisi persaingan yang intensif dari nilai produk lainnya yang ditawarkan pesaing.

Penelitian yang dilakukan Ulaga (2001: 317) menyimpulkan bahwa nilai pelanggan yang superior yang disampaikan oleh perusahaan (delivering superior value to customer) akan mengarahkan pada nilai perusahaan yang superior (superior value of the firm). Proses penciptaan nilai pelanggan meliputi technology delivery, product delivery, dan customer delivery.

Day \& Melvin (2000:55) menyatakan bahwa terdapat dua komponen utama yang menentukan nilai dari suatu produk, yaitu manfaat dan pengorbanan. Benefit termasuk di dalamnya benefit fungsi dan benefit emosi. Pengorbanan termasuk di dalamnya pengorbanan waktu, pengorbanan moneter, pengorbanan energi, dan pengorbanan psikis. Peppers \& Rogers (2011:5) menyatakan perusahaan menghasilkan keuntungan yang lebih baik ketika mereka dapat mengelola nilai pelanggan mereka yang paling banyak memberikan keuntungan bagi perusahaan.

Berdasarkan pernyataan Kotler \& Keller (2012:147), Cravens (2009:7), He (2001:1172), Ulaga (2001:317), Day \& Melvin (2000:55), dan Peppers \&Rogers (2011:5) di atas dapat disimpulkan bahwa perusahaan yang menaruh perhatian pada nilai pelanggan yang superior akan mengarahkannya pada nilai perusahaannya yang superior pula bahkan mendominasi pasar, baik dari pertumbuhan pendapatan, laba, maupun valuasi pasar.

Smith \& Colgate (2007:15), Cravens (2009:3), Kotler \& Keller (2012:147), dan Nasution (2004:18) menyimpulkan bahwa perusahaan yang mengadopsi market driven strategy didasarkan pada logika bahwa semua keputusan strategi bisnis harus dimulai dengan memahami secara jelas tentang pasar, pelanggan, dan pesaing. Market driven strategy yang berorientasi pada pasar memfokuskan perhatian pada pelanggan, pesaing, dan semua fungsi organisasi untuk menciptakan superior customer value.

Wahyuningsih (2004:9) mengungkapkan ada tiga komponen nilai, yaitu nilai fungsional (functional value), nilai sosial (social value) dan nilai emosional (emotional value). Customer value merupakan perbedaan antara total benefit dan total pengorbanan yang dirasakan pelanggan. Total manfaat yang diterima pelanggan (total customer benefit) meliputi manfaaat fungsional, manfaat sosial dan manfaat emosional. Sedangkan total pengorbangan (total sacrifice) meliputi pengorbanan sosial dan pengorbanan emosional.

\section{Teori Dependensi Pelanggan}

Barnes (2011:123) menyatakan bahwa menjaga hubungan pelanggan harus disiapkan oleh penyedia produk atau jasa sebelum produk atau jasa tersebut ditawarkan, sehingga pelanggan dapat mengetahui dan merasakan manfaat dari produk atau jasa dalam jangka panjang. Menyadari manfaat dari produk atau jasa yang diterima oleh pelanggan dibandingkan dengan nilai produk atau jasa yang diberikan pesaing, akan membuat pelanggan setia dan tergantung pada produk atau jasa perusahaan.

Dependensi pelanggan terhadap perusahaan terjadi karena kemampuan perusahaan dalam menggunakan berbagai manfaat (benefits) seperti akses ke lokasi (access to locations), kemitraan (partnerships), dan kemampuan karyawan (the ability of employees). Kemampuan karyawan untuk mengidentifikasi pelanggan secara individual merupakan hal yang juga penting dalam membangun ketergantungan atau dependensi pelanggan. Pelanggan akan menyadari arti pentingnya dan tidak akan melihat dan membandingkan dengan produk 
atau jasa pesaing.

Dependensi pelanggan menjadi penting ketika ada produk serupa atau jasa yang ditawarkan oleh pesaing, sehingga pelanggan akan terikat oleh perusahaan bukan pada pesaing karena pelanggan merasa atau menerima nilai yang tinggi dari perusahaan. Dependensi dapat dibentuk dari hasil hubungan pelanggan yang terus dibangun dan dikelola oleh perusahaan. Kemampuan karyawan dalam membangun hubungan dengan pelanggan melalui kesadaran akan kebutuhan pelanggan sehingga pelanggan merasa istimewa, merasa kemudahan akses ke lokasi strategis perusahaan, dan merasakan kualitas produk atau jasa yang ditawarkan oleh perusahaan.

Oesman (2010:308) menyatakan bahwa dengan menyadari manfaat dari produk atau jasa yang diterima oleh pelanggan akan memberikan nilai produk atau jasa yang lebih tinggi dari pesaing yang akan membuat pelanggan tergantung atau dependensi pada produk atau jasa perusahaan.

\section{Hubungan Kualitas Pelayanan, Manajemen Korelasian Pelanggan, Nilai Pelanggan, dan Dependensi Pelanggan}

Kotler \& Amstrong (2012:265) menyatakan bahwa kualitas pelayanan harus mampu memenuhi atau melebihi harapan pelanggan, sehingga dapat membangun hubungan pelanggan (customer relationship) yang baik. Di samping itu, Kandampully (1998:432) menyatakan bahwa perubahan fokus kualitas jasa sebagai alat bersaing ke arah membangun hubungan emosional jangka panjang yang superior melalui loyalitas jasa (memenuhi bahkan melebihi ekspektasi pelanggan dengan memelihara komitmen dalam menjaga pelayanan). Hal tersebut didukung pula dengan penelitian yang dilakukan oleh Fatima \& Razzaque (2010: 5) yang mengungkapkan bahwa kualitas pelayanan dan keterlibatan pelanggan melalui interaksi langsung tatap muka antara karyawan front-liner dengan pelanggan akan berdampak pada kepuasan pelanggan.

Zineldin (2006: 330) menyatakan bahwa perusahaan harus membangun kerelasian pelanggan yang mampu mengantarkan nilai terkait dengan produk inti.Albrecht \& Zemke (1985), McCormick (1988), dan Booms \& Bitner (1981) dalam Kandampully (1998:435) menyatakan bahwa dalam suatu ekonomi jasa (service economy), kerelasian (relationships) menjadi lebih penting daripada produk fisik (physical products). Bisnis menjadi tiada artinya apabila tidak ada kerelasian (relationships), dan dalam industri jasa (service industries) kerelasian (relationships) merupakan suatu proses interaktif. Dari hasil penelitian yang dilakukan oleh Kandampully (1998:434) organisasi jasa memiliki komitmen kepada pelanggan, yang diwujudkan dalam kegiatan yang dilakukan oleh organisasi tersebut untuk mengembangkan hubungan jangka panjang dengan pelanggan, mempengaruhi pelayanan yang setia, setiap saat, sepanjang waktu.

Kotler \& Amstrong (2012:265) dan Kandampully (1998: 432), Fatima \& Razzaque (2010: 5), Zineldin (2006: 330), Kandampully (1998: 434), dan Albrecht \& Zemke (1985), McCormick (1988) dan Booms \& Bitner (1981) dalam Kandampully (1998:435) dapat disimpulkan bahwa kualitas pelayanan yang sesuai melebihi harapan pelanggan memiliki keterikatan dengan membangun hubungan pelanggan (customer relationship) jangka panjang yang superior yang harus dibangun oleh perusahaan mengingat kerelasian (relationships) menjadi lebih penting daripada produk fisik (physical products) dalam suatu ekonomi jasa. Penelitian dan pernyataan pakar sebagaimana yang dikemukakan oleh Kotler \& Amstrong (2012: 265), Kandampully (1998: 432), Fatima \& Razzaque (2010:5) dan Zineldin (2006: 330), dan Kandampully (1998:434) di atas dapat dinyatakan bahwa cukup kuat adanya hubungan antara kualitas pelayanan dengan manajemen kerelasian pelanggan.

Kotler \& Amstrong (2012: 31) menyatakan bahwa penyampaian pelayanan yang baik dan berkualitas, akan menciptakan nilai jasa yang tinggi yang pada akhirnya dapat memberikan kepuasan kepada pelanggan. Lovelock\& Wirtz (2011: 98) menyatakan bahwa kualitas pelayanan meliputi fasilitas fisik (physical support) dan keterlibatan personil (contact personnel) dari sebuah produk jasa ditujukan untuk menciptakan nilai bagi pelanggan.

Zineldin (2006: 329) dalam hasil penelitiannya memberikan kesimpulan bahwa perusahaan akan memiliki keunggulan kompetitif jika perusahaan mampu menyediakan nilai pelanggan yang superior dibandingkan yang ditawarkan oleh pesaingnya. Perusahaan harus mengevaluasi kualitas pelayanan yang ditawarkannya khususnya kualitas pelayanan yang bersifat intangible sejalan dengan strategi operasi 
yang diimplementasikannya.

Zeithaml \& Bitner (1996) dalam Kandampully (1998:433) menyatakan bahwa pelanggan akan cenderung loyal pada organisasi jasa apabila nilai yang ditawarkannya lebih besar daripada yang diharapkannya dari pesaing. Kualitas jasa merupakan salah satu komponen dari kepuasan pelanggan. Berdasarkan pernyataan Kotler \& Amstrong (2012:31), Heskett (2008) yang dikutip dalam Fitzsimmons (2011:210), Lovelock\& Wirtz (2011:98), Zineldin (2006: 329), dan Zeithaml \& Bitner (1996) dalam Kandampully (1998:433) dapat disimpulkan bahwa kualitas pelayanan akan memengaruhi penciptaan nilai pelanggan.

Zineldin (2006:330), Alipour \& Mohammadi (2011: 8), Payne \& Frow (2005:171), McNaughton et al. (2002:12), Cravens (2009: 217), Peppers \& Rogers (2011: 34), Devaraja (2012:19), Ravald \& Gronroos (1996) dalam Wahyuningsih (2004:5), dan Sheth \& Parvatiyar (2001: 5) dapat disimpulkan bahwa perusahaan harus membangun manajemen kerelasian pelanggan yang mampu menghantarkan nilai pelanggannya.

Berdasarkan kerangka pemikiran dan permasalahan penelitian, maka dapat dirumuskan hipotesis sebagai berikut: (1) kualitas pelayanan dan manajemen kerelasian pelanggan berpengaruh terhadap nilai pelanggan secara simultan; (2) kualitas pelayanan berpengaruh terhadap nilai pelanggan; (3) manajemen kerelasian pelanggan berpengaruh terhadap nilai pelanggan; (4) nilai pelanggan berpengaruh terhadap dependensi pelanggan.

Rosyad (2011:214) menyatakan bahwa penelitian explanatory survey dengan maksud menganalisis hubunganhubungan variabel penelitian dan hipotesis. Populasi sasaran, yaitu sebanyak 63.015 pelanggan bengkel resmi SUV Premium di Jawa Barat. Pengambilan data primer berupa himpunan informasi yang diperoleh dari survei dengan metode observasi, wawancara, dan penggunaan kuesioner terstruktur bersifat tertutup. Pengambilan data sekunder berupa data yang diperoleh dari pihak dealer resmi SUV Premium milik ATPM di Jawa Barat seperti data laporan kinerja, brosur, katalog, dan lain sebaginya dan juga data yang diperoleh dari pihak kedua berupa data hasil-hasil studi, baik studi literatur maupun data dari Gaikindo, BPS, Kementerian Perindustrian, dan Iain sebagainya.
Instrumen penelitian berupa kuesioner diuji validitas dan reliabilitasnya kepada 30 responden dan menunjukkan bahwa tidak terdapat satupun nilai yang berada di bawah batas koefisien korelasi 0,30 sebagaimana dikemukakan oleh Sugiyono (2009: 114) , sehingga seluruh pertanyaan kuesioner penelitian adalah valid. Hasil uji reliabilitas (test of reliability) menggunakan koefisien Alpha Cronbach's diperoleh nilai koefisien sebesar 0,85>0,70 menunjukkan kuesioner yang digunakan reliabel sesuai dengan yang diungkapkan oleh Sekaran (2010: 325).

Kemudian dari data yang diperoleh dari penyebaran kuesioner kepada 400 responden dilakukan pengujian normalitas data dengan menggunakan Chi Kuadrat untuk setiap variabel penelitian menunjukkan hasil bahwa data nilai statistik 400 responden tersebut dapat dinyatakan berdistribusi normal. Kemudian dilakukan pengujian kelayakan model yang menunjukkan hasil bahwa model penelitian telah memenuhi the goodness of econometric model atau karakteristik yang diharapkan, sehingga model tersebut layak untuk digunakan dalam penelitian yang sama pada waktu dan tempat yang berbeda (Wirasasmita, 2007: 1).

Selanjutnya pengolahan data penelitian dilakukan tranformasi dari data ordinal menjadi data interval dengan menggunakan Method of Successive Interval (MSI) dan kemudian dianalisis dengan menggunakan analisis jalur (path analysis). Untuk menggambarkan hubungan kausalitas antar variabel yang diteliti pada penelitian ini digunakan diagram jalur (path diagram) menggunakan SPSS versi 16.0. Adapun penjelasan persamaan jalur dalam penelitian ini dapat diuraikan sebagai berikut:

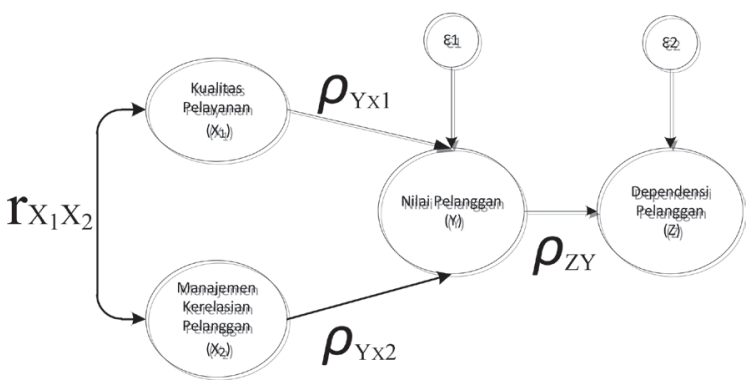

Gambar 3. Diagram Model Penelitian

Persamaan struktural :

$Y=\rho_{Y} X_{1} X_{1}+\rho_{Y} X_{2} X_{2}+\rho_{Y} X_{3} X_{3}+\varepsilon_{1}$

$Z=\rho_{Z Y} Y+\varepsilon_{2}$

Di mana:

$\mathrm{Y}=$ Dependensi Pelanggan 
$\mathrm{X}_{1}=$ Kualitas Pelayanan

$\mathrm{X}_{2}=$ Manajemen Kerelasian Pelanggan

$\varepsilon_{1}=$ Pengaruh variabel lain di luar struktur model 1

$\varepsilon_{2}=$ Pengaruh variabel lain di luar struktur model 2

Untuk menguji hipotesis dilakukan melalui hipotesis statistik dengan menggunakan analisis jalur, sebagai berikut: (1) untuk menguji hipotesis tentang adanya pengaruh secara parsial dari variabel $X$ terhadap Y; (2) untuk menguji hipoteis tentang adanya pengaruh secara simultan dari variabel $X$ terhadap $Y$; (3) untuk menguji hipoteis tentang adanya pengaruh dari variabel $Y$ terhadap $Z$.

\section{Hasil dan Pembahasan}

Berdasarkan hasil perhitungan analisis jalur diperoleh korelasi yang positif di antara kedua variabel bebas. Adapun derajat hubungan dalam kategori rendah (Sugiyono, 2112:184). Berdasarkan hasil perhitungan analisis jalur dan hasil pengujian hipotesis secara parsial dari variabel X (kualitas pelayanan dan manajemen kerelasian pelanggan) terhadap variabel $Y$ (nilai pelanggan), maka dapat disimpulkan bahwa ketiga variabel $X$ tersebut secara parsial memberikan pengaruh yang signifikan.

Besaran koefisien jalur dari masingmasing variabel bebas terhadap variabel terikat dapat dilihat pada tabel 1 .
Tabel 1

Koefisien Jalur Variabel $\mathbf{X}$ terhadap Variabel $Y$

\begin{tabular}{|l|l|}
\hline \multicolumn{1}{|c|}{ Variabel } & $\begin{array}{l}\text { Koefisien } \\
\text { Jalur }\end{array}$ \\
\hline Kualitas Pelayanan $\left(\mathrm{X}_{1}\right)$ & 0,596 \\
\hline $\begin{array}{l}\text { Manajemen Kerelasian Pelanggan } \\
\left(\mathrm{X}_{2}\right)\end{array}$ & 0,243 \\
\hline
\end{tabular}

Sumber: Hasil Pengolahan Data

Berdasarkan tabel 1 di atas, maka dapat diperoleh persamaan jalur, sebagai berikut:

$Y=0,596 X_{1}+0,243 X_{2}+\varepsilon_{1}$

Urutan besaran pengaruh dari masingmasing variabel $\mathrm{X}$ terhadap $\mathrm{Y}$ dapat dilihat pada Tabel 2. Kualitas pelayanan berpengaruh secara signifikan terhadap nilai pelanggan. Pengaruh langsung dan tidak langsung variabel kualitas pelayanan terhadap nilai pelanggan sebesar 39,85\%

Manajemen kerelasian pelanggan berpengaruh secara signifikan terhadap nilai pelanggan. Pengaruh langsung dan tidak langsung variabel manajemen kerelasian pelanggan terhadap nilai pelanggan sebesar $10,23 \%$. Pengujian hipotesis parsial pengaruh variabel $X$ terhadap variabel $Y$ dapat diringkas dalam Tabel 3.

Pengujian hipotesis simultan pengaruh variabel $X$ terhadap variabel $Y$ dapat diringkas dalam Tabel 4. Berdasarkan tabel tersebut, terlihat bahwa $\mathrm{F}_{\text {hitung }}$ adalah 172,355. Tingkat $a=5 \%$ diperoleh nilai $F_{\text {tabel }}$ adalah. (172,355>

Tabel 2

Besaran Pengaruh Langsung dan Tidak Langsung Variabel $\mathbf{X}$ terhadap Variabel $Y$

\begin{tabular}{|c|c|c|c|c|}
\hline \multirow{2}{*}{ Var } & \multirow{2}{*}{$\begin{array}{c}\text { Pengaruh } \\
\text { Langsung }\end{array}$} & \multicolumn{2}{|c|}{ Pengaruh Tidak Langsung } & Total Pengaruh Langsung dan Tidak \\
\cline { 3 - 3 } & $\mathrm{X}_{1}$ & $\mathrm{X}_{2}$ & \\
\hline $\mathrm{X}_{1}$ & 0,3552 & & 0,0433 & 0,3985 \\
\hline $\mathrm{X}_{2}$ & 0,0590 & 0,0433 & & 0,1023 \\
\hline \multicolumn{3}{|l|}{ Total Pengaruh $\mathrm{X}$ terhadap $\mathrm{Y}$} & 0,5008 \\
\hline
\end{tabular}

Sumber: Hasil Pengolahan Data

Tabel 3

Ringkasan Pengujian Koefisien Jalur X terhadap $\mathbf{Y}$

\begin{tabular}{|c|c|c|c|c|}
\hline Struktural & Koefisien Jalur & $\begin{array}{c}\text { Nilai } \\
t_{\text {hitung }}\end{array}$ & $\begin{array}{c}\text { Nilai } \\
t_{\text {tabel }}\end{array}$ & Kesimpulan \\
\hline$\rho_{Y_{1} 1}$ & 0,596 & 17,871 & 1,98 & Signifikan \\
\hline$\rho_{Y \times 2}$ & 0,243 & 7,267 & 1,98 & Signifikan \\
\hline
\end{tabular}

Sumber: Hasil Pengolahan Data 
Tabel 4

Ringkasan Pengujian Simultan Varibel $X$ terhadap $Y$

\begin{tabular}{|ll|c|c|c|c|c|}
\hline \multicolumn{1}{|c|}{ Model } & Sum of Squares & DF & Mean Square & $\mathrm{F}$ & Sig. \\
\hline 1 & Regression & 21154,720 & 1 & 5288,680 & 172,355 &, $000^{\text {a }}$ \\
& Residual & 10187,375 & 399 & 30,685 & & \\
\cline { 2 - 5 } & 31342,095 & 400 & & & \\
\hline
\end{tabular}

Sumber: Hasil Pengolahan Data

Tabel 5

Ringkasan Pengujian Koefisien Jalur Y terhadap Z

\begin{tabular}{|c|c|c|c|c|}
\hline Struktural & Koefisien Jalur & $\begin{array}{c}\text { Nilai } \\
t_{\text {hitung }}\end{array}$ & $\begin{array}{c}\text { Nilai } \\
t_{\text {tabel }}\end{array}$ & Kesimpulan \\
\hline$\rho_{\mathrm{ZY}}$ & 0,8890 & 29,4231 & 1,98 & Signifikan \\
\hline
\end{tabular}

Sumber: Hasil Pengolahan Data

2,70 ) atau nilai signifikansi $0,000<0,05$, maka $\mathrm{H}_{0}$ ditolak.

Kualitas pelayanan dan manajemen kerelasian pelanggan berpengaruh secara simultan dan signifikan terhadap nilai pelanggan sebesar $75.59 \%$, sedangkan pengaruh variabel lain di luar model adalah sebesar $24,41 \%$.

Adapun persamaan jalur untuk variabel $Y$ terhadap $Z$ yaitu: $Z=0,8890 Y+\varepsilon_{2}$. Pengujian hipotesis parsial pengaruh variabel $Y$ terhadap variabel Z dapat diringkas dalam Tabel 5.

Nilai pelanggan berpengaruh secara signifikan terhadap dependensi pelanggan sebesar 79,03\%, sedangkan pengaruh variabel lain di luar model adalah 20,97\%.

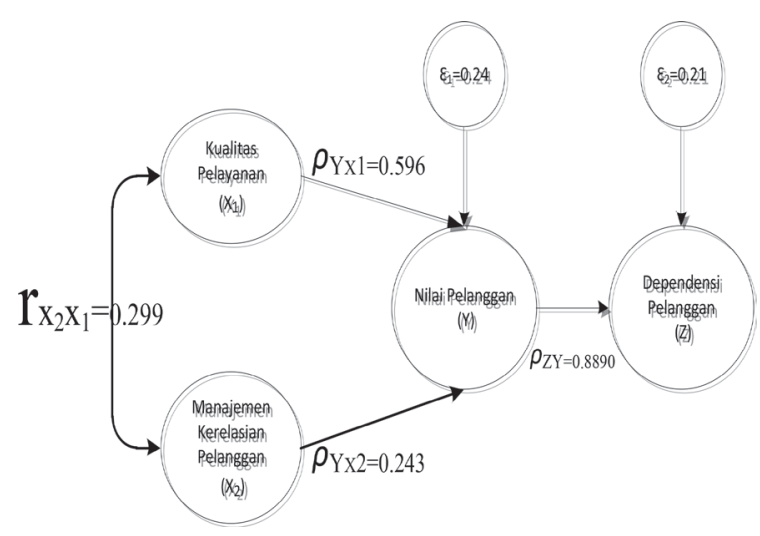

Gambar 4. Diagram Hasil Penelitian

Berdasarkan hasil perhitungan analisis jalur dan hasil pengujian hipotesis secara parsial dari variabel kualitas pelayanan dan manajemen kerelasian pelanggan terhadap nilai pelanggan, maka dapat disimpulkan bahwa kedua variabel bebas tersebut memberikan pengaruh yang signifikan.
Kualitas pelayanan merupakan variabel yang memberikan pengaruh terbesar terhadap nilai pelanggan dibandingkan dengan variabel lainnya. Hal ini dapat dipahami karena kualitas pelayanan yang tepat akan mampu mengoptimalkan nilai pelanggan. Sedangkan variabel yang memiliki pengaruh kecil adalah manajemen kerelasian pelanggan. Hal ini dapat dipahami mengingat manajemen kerelasian pelanggan belum sepenuhnya dioptimalkan penerapannya dalam meningkatkan nilai pelanggan mengingat keterbatasan orang, proses, dan teknologi yang dimiliki setiap bengkel resmi.

Hasil tersebut mendukung teori yang dikemukakan oleh Kotler \& Amstrong (2012: 265) dan Kandampully (1998: 432), Fatima \& Razzaque (2010:5) Zineldin (2006:330), Kandampully (1998: 434), dan Albrecht \& Zemke (1985), McCormick (1988) dan Booms \& Bitner (1981) dalam Kandampully (1998:435) yang menyatakan cukup kuat adanya hubungan antara kualitas pelayanan dengan manajemen kerelasian pelanggan. Kotler \& Amstrong (2012:31), Heskett yang dikutip dalam Fitzsimmons (2011:210), Lovelock\& Wirtz (2011:98), Zineldin (2006:329), dan Zeithaml \& Bitner (1996) dalam Kandampully (1998:433) yang disimpulkan bahwa kualitas pelayanan akan mempengaruhi penciptaan nilai pelanggan. Zineldin (2006:330),Alipour \& Mohammadi (2011:8), Payne \& Frow (2005:171), McNaughton et al. (2002:12), Cravens (2009: 217), Peppers \& Rogers (2011:34), Devaraja (2012:19), Ravald \& Gronroos (1996) dalam Wahyuningsih (2004:5), dan Sheth \& Parvatiyar (2001:5) dapat disimpulkan bahwa perusahaan harus membangun manajemen kerelasian pelanggan yang 
mampu menghantarkan nilai pelanggannya. Berdasarkan hasil hasil perhitungan analisis jalur dan hasil pengujian hipotesis secara simultan dari variabel kualitas pelayanan dan manajemen kerelasian pelanggan terhadap nilai pelanggan, maka dapat disimpulkan kedua variabel bebas tersebut memberikan pengaruh yang signifikan sebesar $75,59 \%$.

Berdasarkan hasil analisis data yang menghitung besaran pengaruh dan pengujian hipotesis nilai pelanggan terhadap dependensi pelanggan, maka diperoleh besaran pengaruhnya sebesar $79,03 \%$ dan signifikan. Dengan demikian hal ini menunjukkan bahwa nilai pelanggan memberikan kontribusi yang signifikan dalam meningkatkan dependensi pelanggan bengkel resmi.

Hasil penelitian ini mendukung pendapat Barnes (2011:123) dan Laaksone, Pajunen, dan Kulmala (2007:27), Oesman (2010:308), dan Waheed \& Gaur (2002:1000) yang dapat disimpulkan bahwa perusahan harus meningkatkan nilai pelanggannya dibandingkan yang diberikan pesaing, agar pelanggannya setia dan tergantung/ dependensi pada produk atau jasa perusahaan.

\section{Simpulan dan Saran}

Pertama, Kualitas pelayanan dan manajemen kerelasian pelanggan berpengaruh secara parsial dan signifikan terhadap nilai pelanggan bengkel resmi mobil SUV premium. Pengaruh kualitas pelayanan terhadap nilai pelanggan lebih besar dibandingkan dengan manajemen kerelasian pelanggan; Kedua, kualitas pelayanan dan manajemen kerelasian pelanggan berpengaruh secara simultan dan signifikan terhadap nilai pelanggan bengkel resmi mobil SUV premium. Besaran pengaruh kualitas pelayanan dan manajemen kerelasian pelanggan terhadap nilai pelanggan bengkel resmi mobil SUV premium lebih besar dibandingkan dengan besarnya pengaruh variabel lainnya; Ketiga, nilai pelanggan berpengaruh secara signifikan terhadap dependensi pelanggan bengkel resmi mobil SUV premium.

Saran dari hasil penelitian ini adalah bahwa perusahaan sebaiknya memfokuskan pada kualitas pelayanan dibandingkan dengan manajemen kerelasian pelanggan dalam meningkatkan nilai pelanggan; di samping, itu perusahaan perlu mengoptimalkan manajemen kerelasian pelanggan yang masih memiliki keterbatasan, baik dari sisi orang, proses, dan teknologi, yang dimiliki setiap bengkel resmi.

\section{Daftar Pustaka}

Alipour, Mehrdad and Mohammadi, Hallaj Mohammad. (2011). "The Effect of Customer Relationship Management (CRM) on Achieving Competitive Advantage of Manufacturing Tractor".Global Journal of Management and Business Research, Vol. 11 , No. 5, pp. 1-9

Barnes, James G. (2011). Secrets ofCustomer Relationship Management, First Edition, Singapore: MCGraw Hill.

Buttle, Francis. (2005). Customer Relationship Management:Concepts \& Tools, First Edition,Oxford: Elseiver, Ltd.

Cravens, W. David. and Piercy, F. Nigel. (2009). Strategic Marketing, NinthEdition, Singapore: McGraw Hill/ Irwin.

Day, Ellen. and Crask, R Melvin. (2000). "Value Assessment: The Antecedent of Customer Satisfaction". Journal of Consumer Satisfaction, Dissatisfaction, and Complaining Behavior, Vol. 13, pp. 52-60

Devaraja, T.S. (2012). "An Overview of Customer Relationship Management and Customer Value in Information Technology Industry". Working Paper at University of Mysore- India, pp. 1-27

Ehinlanwo, Olajide Omotuyi \& Zairi, Mohamed. (1996). Best Practice in The Car AfterSales Service: An Empirical Study of Ford, Toyota, Nissan, and Fiat in Germany. Business Process Re-engineering \& Management Journal, Vol.2, No.1 \& 2, pp 39-56

Fatima, J.K., and Razzaque, A.M. (2010)."Understanding The Role of Service Quality, Customer Involvement and Rapport on Overall Satisfaction in Bangladesh Banking Service". Working Paper of University of New South Wales, pp.1-8

Fitzsimmons, A. James. and Fitzsimmons, J. Mona. (2011). Service Management:Operation, Strategy, Information Technology, Seventh Edition, Singapore: McGraw Hill/ Irwin.

Gaikindo dan Dispenda Jawa Barat dan Banten. (2013). "Laporan Kendaraan Bermotor 2010-2012," Bandung.

Hardiansyah. (2012). "Analisis Kualitas Pelayanan Izin Mendirikan Bangunan pada Dinas Tata Kota di Kota Palembang." MIMBAR, Vol.28, No. 2, pp.191-199

He, Gao. (2001). "Research on The Measurement of Customer Value: The Cas fo Cell Phone Industry". Industrial Marketing Management, No. 30, pp. 339- 
351.

Kandampully, Jay. (1998). "Service Quality to Service Loyalty: A Relationship Wich Goes Beyond Customer Services."Total Quality Management, Vol. 9, No. 6, pp. 431-443

Kottler, Philip. and Amstrong, Gary. (2012). Principles of Marketing, Fortinth Edition, New York: Pearson Educated, Limited

Kottler, Philip. and Keller, L. Kevin. (2012). Marketing Management, Fortinth Edition, New York: Pearson Educated Limited.

Lovelock, Christopher. and Wirtz, Jochen. (2011). Services Marketing:People, Technology, Strategy, Seventh Edition, New Jersey: Pearson Education, Inc.

McNaughton, Rod B. Osborn, Phil. and Imrie, C Brian.(2002). "Market Oriented Value Creation in Service Firms", Working Paper at University of Waterloo-Canada, pp. 1-24.

Nasution, Hanny H. (2004). "A Study of Customer Value in The Indonesian Hospitality Industry". Usahawan, Vol. XXXIII No. 28, pp. 11-18.

Nurmayanti. (2013)."Komunitas Ekonomi ASEAN Pangkas Dominasi Produsen Otomotif Jepang",http://bisnis.liputan6. $\mathrm{com} / \mathrm{read} / 511421$, diunduh pada 31 Maret 2014.

Oesman, Y.M. (2010). Sukses Mengelola Marketing Mix, CRM, Customer Value, dan Customer Dependency: Kasus pada Pemasaran Shopping Center, Bandung: Alfabeta.

Payne, Adrian. and Pennie Frow. (2005). "A Strategic Framework for Customer Relationship Management." Journal of Marketing, Vol. 69, pp. 167-176.

Peppers, Don. and Rogers, Martha. (2011). Managing Customer Relationships:A Strategic Framework, Second Edition, New Jersey: John Willey \& Sons.

Rosyad, Udung Noor. (2011). "Pengaruh Komunikasi Pemasaran terhadap Perluasan
Pangsa Pasar," MIMBAR, Vol.XXVII, No. 2, pp.213-224.

Sekaran, Uma. and Bougie, Roger. (2010). Research Methods fo Business: A Sill Building Approach, Fifth Edition, Southern Gate: John Willey \& Sons.

Sheth, Jagdish N. and Parvatiyar, Atul. (2001). "Customer Relationship Management: Emerging Practice, Process, and Discipline," Journal of Economic and Social Research, Vol.3, No.2, pp.1-34.

Smith, Brock J. and Colgate, Mark. (2007). "Customer Value Creation." Journal of Marketing Theory and Practice, Vol. 15, No.1, pp. 7-23.

Sugiyono. (2012). Metode Penelitian Kuantitatif, Kualitatif, dan R\&D, Bandung: Alfabeta.

Tanoso, Harry. (2012). "Ini Alasan Kenapa Honda CRV Merajai SUV di Indonesia,"http://www.marketing.co.id/ blog/2012/07/25, diunduh pada 31 Maret 2014.

Ulaga, Wolfgang. (2001). "Customer Value in Business Market,"Industrial Marketing Management, No.30, pp. 315-319.

Wahyuningsih. (2004). "Customer Value: Concept, Operationalization, and Outcome, Usahawan," No.28, Th. XXXIII, pp. 3-10

Wirasasmita, Yuyun. (2007). "Uji Kelayakan Model: Extended Handout Metode Penelitian Ekonomi dan Bisnis," Bandung: UNPAD.

Zeithaml, A. Valarie. Bitner, J. Mary. and Gremler, D. Dwayne. (2009). Services Marketing:Integrating Customer Focus Across the Firm, Fifth Edition, Singapore: McGraw Hill/ Irwin.

Zineldin, Mosad. (2006). "Quality and Customer Relationship Management (CRM) as Competitive Strategy in The Swedish Banking Industry,"The TQM Magazine, Vol.17, No.4, pp. 329-344. 